\title{
Pandangan Tokoh Agama Islam dalam Menyikapi Pandemi Covid-19
}

\section{Siti Nurjanah ${ }^{1 *}$, Mohammad Taufiq Rahman ${ }^{2}$, Ilim Abdul Halim ${ }^{3}$}

1 Magister Studi Agama-Agama UIN Sunan Gunung Djati Bandung, Indonesia; sitinurjannah591@gmail.com

2 UIN Sunan Gunung Djati Bandung, Indonesia; fikrakoe@uinsgd.ac.id

3 UIN Sunan Gunung Djati Bandung, Indonesia; ilimhalim@uinsgd.ac.id

* Correspondence

Received: 2021-06-16; Accepted: 2021-08-11; Published: 2021-08-17

\begin{abstract}
Abstrak: Permasalahan Covid-19 yang terus menerus menghantui kehidupan publik berdampak pada pelaksanaan keagamaan di masyarakat. Untuk itu, agama tergerak sendiri untuk menanggulangi pencegahan yang dilakukan. Sebenarnya, agama berperan sangat penting dalam mengatur kehidupan manusia, sehingga tokoh agama selalu dinantikan dalam memberikan bimbingan dan doktrin agama dalam menyikapi covid 19. Tujuan penelitian ini adalah untuk mengetahui mengenai pandangan dari para tokoh agama Islam dan dari doktrin keagamaan itu sendiri dalam menyikapi pandemic Covid-19. Metode yang digunakan yaitu menggunakan metode penelitian kualitatif deskriptif. Sumber data primer adalah sumber yang diambil langsung kepada tokoh-tokoh organisasi keagamaan seperti Nahdlatul Ulama, Persatuan Islam, dan Muhammadiyah yang ada di Kota Bandung. Adapun sumber data sekunder adalah literatur seperti buku, jurnal-jurnal dan karya ilmiah lainnya, sehingga data tersebut dapat terkumpul dengan tersusun secara sistematis. Analisis data dilakukan dengan beberapa macam yaitu reduksi data, penyajian data dan verifikasi. Lembaga keagamaan juga memiliki peran terhadap masyarakat dalam menyikapi wabah Covid-19 yaitu bergerak dalam menolong masyarakat, memberikan solusi dan kontribusi sesuai aturan pemerintah kepada masyarakat. Dalam masalah peribadatan, masyarakat harus mengetahui apakah aturan ibadah berjama'ah diperbolehkan atau tidak, dan apakah tempat-tempat sakral lainnya diijinkan untuk tetap didatangi atau tidak. Itu semua masuk pada peran lembaga keagamaan dalam membimbing masyarakat.
\end{abstract}

Kata Kunci: Doktrin keagamaan; organisasi kemasyarakatan; peran social; peraturan pemerintah; tempat sakral.

Abstract: The Covid-19 problem that continues to haunt public life impacts the implementation of religion in society. For this reason, faith has moved itself to overcome the prevention that has been carried out. Religion plays a significant role in regulating human life, so religious leaders are always expected to provide guidance and religious doctrine in responding to covid 19. The purpose of this study was to find out about the views of Islamic religious leaders and from religious doctrine itself in responding to the Covid pandemic. -19 . The method used is the descriptive qualitative research method. Primary data sources are sources taken directly from religious organization figures such as Nahdlatul Ulama, Persatuan Islam, and Muhammadiyah. The secondary data sources are literature such as books, journals, and other scientific works to collect data systematically. Data analysis was carried out in several ways, namely data reduction, data presentation and verification. Religious institutions also have a role in the community in responding to the Covid-19 outbreak, namely moving in helping the community, providing solutions and contributing according to government regulations to the community. In matters of worship, the community must know whether the rules of congregational worship are allowed or not and whether other sacred places are allowed to be visited. It all goes into the role of religious institutions in guiding the community.

Keywords: Community organizations; government regulations; religious doctrine; sacred place; social role. 


\section{Pendahuluan}

COVID-19 (Corona Virus Disease) merupakan virus yang sangat ganas menimpa dunia, awal mula adanya virus ini diklaim berasal dari Cina tepatnya daerah Wuhan. Adapun Cina mengklaim juga Corona muncul karena terdapat pengiriman impor dari luar yang masuk ke Cina. Kasus pertama kali muncul diyakini berasal dari pasar basah Wuhan (Darmawan, Miharja, Waluyajati, \& Isnaeniah, 2020; Darsono, Rohmana, \& Busro, 2020). Kemudian muncul banyak misteri dan pandangan yang menyimpulkan mengenai Covid-19 termasuk ungkapan tersebut dikatakan oleh kepala dari organisai WHO (World Health Organization) (Usman, 2020). Banyak sekali dampak karena kasus adanya Covid19 yang mempengaruhi pemikiran pada masyarakat dunia. Puncaknya ketika pemerintah mulai menentukan dan memutuskan kebijakan-kebijakan baru kepada negaranya, masyarakat yang mulai tertekan dan kebingung akan berlari kemana, dan pencegahan seperti apa yang harus dilakukan. Salah satu contohnya dampak dalam menjalankan ibadah. Untuk mengurangi penyebaran virus, pemerintah memberikan kebijakan penutupan tempat ibadah yang diatur oleh Permenkes No.3 tahun 2020 mengenai PSBB (Pembatasan Sosial Berskala Besar) menyebutkan pada ayat 13 bahwa semua tempat ibadah ditutup. Setelah perintah itu diterbikan baik semua tempat ibadah dan tempat jiarah-jiarah pada semua agama dihentikan dari kegiatan berjamaah tanpa terkecuali (Tado, 2020). Kejadian tersebut jelas menjadi fenomena unik ketika masih ada umat yang semangat untuk menjalankan ibadah dan tetap melakukan aktivitas yang sama di tempat ibadah dilakukan secara bersama, sampai kurang melihat anjuran dari pemerintah (Satria, 2020).

Kita ketahui bahwa Corona adalah virus atau makhluk Tuhan yang hanya dilihat melalui alat pembesar, ia memiliki pengaruh dampak buruk terhadap manusia, dapat menyebabkan beragam reaksi termasuk reaksi yang paling tinggi yaitu kematian. Ponis kematian tersebut membuat mental masyarakat melemah, apalagi ketika penyebarannya berlangsung dengan cepat dan sulit menemukan obatnya. Gejala-gejala tingkat tinggi dan rendah menurut medis yang menunjukan terpaparnya Covid19 yaitu tingkat rendah dengan adanya demam, batuk dan sesak nafas. Tingkat yang dikatakan tinggi yaitu sulit bernafas (Rompas, Kawatu, \& Pinontoan, 2020), nyeri pada bagian dada, pusing, bibir atau wajah yang membiru, hilangnya indra penciuman. Gejala tersebut butuh 2 sampai 14 hari untuk menentukan apakah orang tersebut terkena Covid-19 atau tidak, karena awal dari gejala tersebut sulit terlihat. Selama orang memiliki gejala tersebut diharuskan mengisolasikan diri di tempat yang sepi agar tidak terkena penularan Virus.

Sebelum adanya Covid-19 sejarah mengungkapkan bahwa terdapat virus-virus yang lebih mematikan dan muncul seperti wabah penyakit tersebut yaitu dinamakan dengan Mers-Cov (Middle East Respiratory), SARS-CoV (Severe Acute Respiratory Syndrome) (Susilo et al., 2020). Adapun wabah penyakit lainnya ketika jaman Nabi Muhammad, begitupun wabah terjadi ketika jaman para sahabat nabi dinamakan dengan wabah thoun. Tercatat dalam buku yang ditulis oleh Nabil Thawil berjudul "Rahasia Sehat Ala Rasulullah SAW: Belajar Hidup Melalui Hadits-hadits Nabi" pada jaman rosulullah apabila ada daerah yang terkena dengan penyakit yang tidak biasa, yang dapat menular kemudian penyakit itu dinamakan dengan penyakit Tho'un, Rosulullah memerintahkan kepada umatnya untuk melakukan isolasi atau melakukan karantina kepada orang yang terkena penyakit wabah tersebut di mana karantina tersebut jauh dari kawasan daerah pemukiman warga (Supriatna, 2020).

Pencegahan terus dilakukan oleh berbagai pihak, pemerintah yang terus menambahkan peraturan kepada masyarakat, agar masyarakat tetap menjaga situasi yang didampak oleh Covid-19 (Suherman, 2020). Dotrin-doktrin terus diberikan kepada masyarakat melalui dakwah media, dakwah secara tertutup serta memberikan motivasi untuk tetap berpikiran positif. Ada beberapa dampak yang terlihat oleh peneliti dalam permasalahan Covid-19 diantara lainnya, dampak dari praktek ibadah, sistem social, sistem ekonomi, politik, serta psikologi yang dirasakan oleh masyarakat. Oleh karena itu masyarakat butuh nilai-nilai agama yang diberikan oleh tokoh agama bertujuan untuk penguatan serta energi pada pengembangan diri (Muchammadun et al., 2021).

Dampak yang disebabkan karena Covid-19 pertama berpengaruh dengan praktek-praktek ibadah yang dilakukan. Sehubungan pemerintah sudah menerapkan PSBB maka sebagian masyarakat mengkritik aturan yang disahkan tersebut. Masyarakat menganggap bahwa adanya Covid-19 tersebut 
dilandaskan adanya permainan politik. Prasangka tersebut membuat masyarat semakin kebingungan, karena prasangka itulah sebagian masyarakat tidak mempercayai pemerintah bahwa adanya wabah Covid-19. Ada sebagian penganut umat beragama menyatakan bahwa, segala apapun yang terjadi Tuhanlah pemberi penyakit dan yang bisa menyembuhkannya. Kata-kata tersebut dijadikan senjata oleh sebagian masyarakat, mereka percya bahwa penyembuh segala penyakit adalah Tuhan. Tetapi siapa sangka bahwa Tuhan juga memerintahkan kepada manusia untuk tetap waspada, dan peringatan itu tertulis dalam kitab sucinya (Muhammad Y Wibisono, Truna, \& Rahman, 2021). Kembali lagi pada permasalahan praktek ibadah yang dilakukan oleh umat ketika pandemi dengan melaksanakan ibadah di rumah. Karena dampak corona sangat besar pada kehidupan umat manusia, sebab itu tempat-tempat ibadah seperti, mesjid, gereja, kuil, dinagog dan tempat jiarah lainnya mengubah tata cara ibadah demi mengurangi penyebaran wabah Covid-19 (Diseko, 2020; Jubba, 2021).

Kebijakan dari lembaga pusat keagamaan yang ada di Indonesia yaitu MUI (Majelis Ulama Indonesia) memberikan perintah bagi umat muslim berupa penetapan fatwa yang isi dari fatwa tersebut No.14 tahun 2020 ibadah dilakukan berdasarkan daerah yang mana yang diperbolehkan dan tidak boleh untuk melaksanakan ibadah berjamaah seperti ibadah solat jum'at. Dijelaskan juga aturanaturan ketika melaksanakan solat wajib tersebut yang terkandung dalam isi ketentuan hokum no 3 yang berisi apabila berada dikawasan yang memiliki potensi penularannya rendah berdasarkan ketetapan dari pihak yang berwenang maka wajib untuk menjalankan ibadah seperti biasa namun tetap menjaga diri, menjaga kontak fisik secara langsung, dan memiliki alat ibadah sendiri, agar tidak terpapar dari Covid-19. Ketetapan tersebut dikuatkan oleh ketetapan lainnya yaitu pada No.5 bahwasannya masyarakat muslim khususnya laki-laki tetap harus melaksanakan ibadah solat jum'at. Namun dengan ketetapan yang disepakati MUI tidak menyertakan bagaimana petunjuk yang detail mengenai pengertian daerah yang menjadi penyebaran Covid-19 rendah dan terkendali (Tado, 2020).

Adanya ketidaksiapan dari masyarakat mengenai ibadah yang dilakukan di rumah. Untuk meredakan perasaan itu, para umat beragama harus dibimbing dan diberikan ilmu dari tokoh keagamaan. Ilmu ini berupa ajaran-ajaran yang diterapkan dalam kehidupan dan ketika menghadapi Covid-19. Kedua yaitu dampak sistem sosial yang dirasakan oleh masyarakat berupa renggangnya jarakan diantara masyarakat atau individu lain. Semua cara penanggulangan Covid-19 telah diberikan kepada masyarakat, tetapi kemudian sebagian sikap masyarakat ada yang acuh atas adanya Covid-19, oleh karena itu sepatutnya tokoh agama memberikan peran dalam menggerakan system kepada masyarakat untuk meningkatkan rasa optimis pada masyarakat ketika pandemik. Sebagian kalangan dari masyarakat yang mampu bahkan lebih mampu dalam mencukupi fasilitas, kebutuhan untuk hidupnya banyak yang meningkatkan kepedulian dengan berkontribusi untuk membantu kalangan yang membutuhkan atau kekurangan dari kebutuhan hidup (Salsabila, 2020).

Tokoh agama yang sangat berpengaruh terdapat di dalam organisasi atau lembaga keagamaan. Mereka-mereka lebih dipentingkan daripada tokoh diluar hokum keagamaan. Jika melihat pemahaman mengenai arti dari tokoh agama bersumber pada orang yang terhubung dengan nabi dengan kata lain tokoh agama yang dimaksud yaitu Ulama. Ulama yaitu orang yang memiliki tingkat keilmuan yang levelnya tinggi. Ia mampu memahami berbagai keilmuan, khususnya ilmu agama serta ilmu lainnya dengan meliputi wawasan pemikiran yang sangat luar. Tokoh agama memegang kendali atau memiliki kedudukan yang tidak pandangan pada tokoh agama harus memiliki nilai dan norma, karena mereka dituntut menjadi manusia yang patut dicontoh oleh masyarakat.

Banyak sekali peran yang dilakukan oleh para tokoh keagamaan, peran tersebut dapat dianalisis dari dalam lembaga agama di Indonesia, khususnya pada lembaga keagamaan Islam. Banyak sekali aliran dan kelompok dalam agama Islam seperti kelompok lembaga masyarakat yaitu Muhammadiyah, Nahdlatul Ulama, PERSIS, dan lain sebagainya. Lembaga yang akan dibahas pada hasil pembahasan yaitu tiga lembaga yang terdapat dan melihat dari tokoh keagamaan masyarakat yaitu, Muhammadiyah, Nahdlatul Ulama dan PERSIS. Berbagai pendapat pasti diuraikan oleh para tokoh agama menyikapi dan memahami Covid-19. Pandangan-pandangan yang dijelaskan kepada masyarakat akan memecahkan serta memberikan pencerahan dalam memerangi dan mencegah penyebaran dari Covid-19. Di dalam lembaga keagamaan peran tokoh agama harus aktif dalam 
memberikan khutbahnya, namun janganpula terus-menerus memberikan nasihat tanpa bergerak untuk membantu dalam masalah ekonomi. Gerakan dari tokoh ini berpengaruh juga dalam system lembaga karena mereka harus memberikan saran serta pendapatnya kepada pemerintah pusat maupun daerah.

Dari pendalaman berkaitan dengan ketiga lembaga tersebut akan mengasilkan pandangan dari tokoh agama yang berbeda yaitu tentang pemahaman Covid-19, bentuk dari doktrin yang diterangkan oleh tokoh keagamaan, ajaran yang diberikan dari agama kepada umat, memberikan ilmu mengenai ibadah yang dilakukan pada masa Covid-19 kepada umat, menjelaskan perilaku atau sikap yang harus diterapkan dengan melalui system dari social keagamaan. Pandangan yang diberikan dari setiap tokoh agama ini akan memberikan saran mengenai pencegahan Covid-19, kemudian gerakan oleh tokoh agama akan menyadarkan bagaimana fungsi dari organisasi agama pada umatnya, sehingga prinsipprinsip yang terdapat pada system dapat mempermudah untuk memecahkan masalah pencegahan Covid-19.

Adapun tujuan penelitian ini yaitu untuk mengetahui mengenai pandangan dari para tokoh agama Islam dan doktrin keagamaan menyikapi pandemic Covid 19. Berkaitan dengan hal ini Wach membagi pemahamaan keagamaan menjadi dua tingkatan, pertama yaitu memiliki sifat integral yang menyeluruh dan partikal yaitu sebagian. Pemahaman tersebut di akui oleh masyarakat dengan memahami suatu agama dalam pemikiran dan membentuk pola tingkah laku sehingga konteks tersebut dapat kita nilai dengan sempurna sehingga dapat memahami nilai pemikiran dengan tepat (Hanafi, Syarifudin, Nurfaizal, \& Nurjanah, 2020). Pemahaman pada agama yaitu mengenai bagaimana pengikutnya memiliki seberapa kuat dan kokoh pada keyakinan, kemudian dapat di lihat dari tindakannya seberapa sering dalam melaksanakan ibadah dan mendalami kaidah, serta dapat melihat bagaimana penganutnya menghayati ajaran pada agamanya (Firdausita, 2018).

Kedua, memahami agama sendiri dan agama lain dengan emosional yang tepat, emosional tersebut dilihat dari perasaan, perhatian, mengikut sertakan dalam kehidupan dan metaxis. Agama dalam pemahaman kedua ini merupakan persoalan dalam pribadi manusia yang rinci dapat melibatkan akal dari manusia, kemudian perasaan dan harapan dari dalam diri manusia. tindakan dari individu merupakan aktivitas yang bersangkutan pada nilai keagamaan baik dari dimensi vertical atau horizontal (Ansyori, 2018).

Ketiga yaitu kemauan, kemauan ini yang akan membertahu kepada manusia yang beragama bahwa pengikut dari agama harus memiliki tujuan konstruktif karena dengan tujuan tersebut pengikut mengetahui hasrat, rasio dan pengendalian pribadi lainnya. Kemudian pengikut diharuskan mempelajari mengenai persoalan agama yang mendalam, luas dan memiliki rasa simpati tinggi yang di wadahi pemahaman mengenai ketaatan beragama (Wach, 2019), perbedaan pemikiran dalam keagamaan dan peribadatan yang memiliki perbedaan dari dalam agamanya.

Joachim Wach mengungkapkan bahwa bentuk dari teoritis atau pemikiran dapat diungkapkan pada doa yang menjadi sarana untuk ungkapan dari gejolak hati ketika mengalami masalah yang sedang dihadapi oleh individu (Pujiastuti, 2017). Bentuk ungkapan yang kedua yaitu mengenai tindakan di mana segala kegiatan bersangkutan dengan agama, dari system kepercayaan, nilai, norma serta kegiatan dari kebiasaan kehidupan yang dijadikan sebagai pedoman dalam menjalani hubungan dengan tuhan serta alam semesta dan lingkungannya. teori Joachim Wach yaitu bentuk ungkapan pengalaman keagamaan yang terbagi dalam tiga bentuk yaitu dalam bentuk pemikiran atau doktrin,bentuk kedua yaitu perbuatan atau Ritual dan yang ketiga yaitu persekutuan atau social pada kehidupan manusia yang di rangkai dalam suatu lembaga kemasyarakatan.

\section{Metode}

Metode yang digunakan yaitu menggunakan metode penelitian kualitatif, Penerapan pada jenis penelitian kualitatif dikatakan agar dapat terjaminnya sifat yang ilmiah. Pendekatan dalam penelitian ini dengan menggunakan pendekatan fenomenologi yang menjelaskan untuk mempelajari setiap hal yang dilihat oleh panca indra sehingga dapat diterangkan dan dinilai secara ilmiah berdasarkan gejala 
yang ada dialam. Fenomenologi yaitu cara untuk mengungkapkan dan menganalisis mengenai fenomena yang memiliki konteks unik dan khas dalam pengalaman oleh individu secara mendalam hingga berupa keyakinan yang bersangkutan dengan individu tersebut (Moleong, 2021). Penelitian deskritif dapat memberikan gambaran jelas perihal masalah ibadah keagamaan saat terjadi adanya penularan wabah Covid 19, dalam penggambaran ini penulis mampu memecahkan masalah dengan menggunakan beberapa rangkaian bahan dalam pengumpulan data.

Sumber data yang digunakan dapat dibagi menjadi dua sumber data yaitu sumber data primer dan sekunder. Sumber data primer yaitu sumber yang diambil langsung kepada tokoh-tokoh agama Islam dari lembaga berikut: Lembaga Nahdlatul Ulama, Lembaga Persatuan Islam, Lembaga Muhammadiyah. Adapun penambahan dari sumber data sekunder yaitu dengan menambahkan data melalui literatur seperti buku, jurnal-jurnal dan karya ilmiah lainnya, sehingga data tersebut dapat terkumpul dengan tersusun.

Cara penggunaan dalam analisis data yaitu dengan beberapa macam yaitu Ruduksi data, penyajian data dan Verifikasi. Reduksi data merupakan data yang diambil akan tercatat lebih rinci dan teliti sehingga data yang didapatkan lebih banyak dan kompleks. Adapula dengan penyajian data, yaitu data yang dapat menyusun menjadi terorganisasikan dalam hubungan dengan alur dari pola penulisan berupa bagan dan uraian singkat. verifikasi ini akan berubah apabila data yang ditemukan tidak benar adanya. Karena dengan data-data yang asli peneliti dapat menyimpulkan dalam pengumpulan data ditemukan dilapangan (Sugiyono, 2009).

\section{Hasil Penelitian}

\section{Pandangan Tokoh Keagamaan tentang Pandemi Covid 19}

\section{Lembaga Muhammadiyah}

Dari tokoh pandangan Muhammadiyah memaparkan bahwa wabah penyakit menular itu diciptakan oleh Allah, karena campur tangan Tuhan lah virus ini muncul, lebih tepatnya Kelik Nursetiyo Widiyanto sebagai ketua Majelis Pustaka mengatakan bahwa, mereka itu adalah makhluk, ketika menyerang manusia yang tugasnya seperti itu, ketika kemudian menjadi bencana bagi manusia, bagi kaum agamawan itu sebuah intropeksi seperti yang terjadi dengan nabi ayub ketika sakit, ia intropeksi memohon ampun karena telah membuat kesalahan, bagi kaum yang lain yang telah diberikan bencana penyakit juga seperti itu, ada yang menerima sebagai intropeksi atau ada yang menerima bencana biasa, jadi tergantung biasa. Sebagai orang yang beriman kita hrus intropeksi baik ketika masih sehat atau sakit (Kelik Nursetiyo Widiyanto, wawancara, 09 April 2021).

Wabah virus covid-19 yaitu suatu makhluk yang tugaskan oleh Tuhan untuk menyerang manusia. Dari segi kacamata agamawan melihat, bahwa adanya wabah penyakit tersebut telah menjadi sebuah bencana bagi manusia, kemudian manusia di haruskan untuk intropeksi diri karena wabah tersebut berdampak terhadap manusia. Kemudian penjelasan wabah dari lembaga Muhammadiyah dari dr.Dian Indahwati sebagai Ketua dari gerakan lembaga MCCC, beliau mengatakan bahwa: Penyakit Virus Corona (Covid-19) adalah penyakit menular yang disebabkan oleh virus corona yang baru-baru ini ditemukan. Sebagian besar orang yang tertular Covid-19 akan mengalami gejala ringan hingga sedang, dan akan pulih tanpa penanganan khusus. Cara penyebaran virus Ini yaitu virus yang menyebabkan Covid-19 terutama ditransmisikan melalui droplet (percikan air liur) yang dihasilkan saat orang yang terinfeksi batuk, bersin, atau mengembuskan nafas. Droplet ini terlalu berat dan tidak bisa bertahan di udara, sehingga dengan cepat jatuh dan menempel pada lantai atau permukaan lainnya. Anda dapat tertular saat menghirup udara yang mengandung virus jika anda berada terlalu dekat dengan orang yang sudah terinfeksi Covid-19. Anda juga dapat tertular jika menyentuh permukaan benda yang terkontaminasi lalu menyentuh mata, hidung, atau mulut Anda (Dian Indahwati, wawancara, 05 Mei 2021).

Paparan dari penjelasan dr.Dian yaitu menjelaskan bagaimana pengertian dari Covid-19 dan bagaimana virus itu bisa menyebar dengan cepat sehingga ditemukan gejala-gejala pada seseorang 
yang terkena dari wabah tersebut. Dari penjelasan dari dr.Dian masuk pada pengertian medis, karena beliau bergerak dalam bidang medis namun gerakan tersebut berasal dari lembaga Muhammadiyah, gerakan tersebut agar meringankan masyarakat dalam penanganan dari adanya wabah Covid-19 yang sedang melanda.

\section{Lembaga Nahdlatul Ulama}

Pandangan mengenai Covid-19 juga dijelaskan oleh lembaga Nahdlatul Ulama (NU). Berikut beberapa tokoh yang menjelaskan bagaimana pandangan dari tokoh keagamaan mengenai Covid-19 berupa penyimpulan yang dipaparkan oleh peneliti. Ada beberapa narasumber yang menjadi acuan peneliti yaitu narasumber pertama Wahyi Afif Algoifi sebagai Sekertaris NU di Kota Bandung beliau mengatakan bahwa, Covid-19 ini kan makhluknya tidak terlihat, makhluk yang sangat kecil Microorganisme, ditambah keadaan manusia yang bermegah-megah. Kemudian membuat kita semakin sadar dengan makhluk-Nya yang tidak terlihat itu, kita semua sudah kalah, negeri- negeri besar seperti Amerika, Afrika, Cina, Italia. Negeri-negeri besar seperti itu semuanya dibuat pora poranda oleh Covid-19, oleh makhluk yang tidak terlihat ini oleh Allah yang tidak terlihat. Mestinya semakin kita menyadari, bahwa Allah itu maha berkuasa atas segala sesuatu, dan kemudian membuat kita semakin takarub illah mendekatkan diri kepada Allah SWT, nah seperti itu (Wahyi Afif Algoifi, wawancara, 05 Mei 2021).

Berkenaan dengan hal tersebut, Covid-19 ini adalah suatu makhluk yang tidak terlihat oleh manusia, sehingga dengan adanya Covid-19 manusia dapat tersadarkan oleh makhluk yang dianggap kecil tersebut namun dapat berdampak sangat buruk bagi manusia, bahkan sampai adanya kematian yang dihadapi oleh manusia. Penjelasan di atas juga dapat menggambarkan bahwa Covid-19 ini akan berdampak pada setiap Negara yang bahkan sampai pada Negara yang besar dan berkembang. Dan pada akhirnya manusia diharuskan kembali kepada sang Maha Pencipta dari virus tersebut.

Berikutnya penjelasan mengenai Covid-19 dari segi keagamaan diperkuat oleh narasumber yang kedua yaitu yaitu Nasrullah Jamal menjabat sebagai Wakil Sekretaris PCNU, beliau memaparkan mengenai virus corona sebagai berikut; "Sebetulnya pandangan covid dari beberapa kalangan baik dimufasirin maupun Ulama itu merupakan salah satu wabah yang sebenarnya bukan hal yang baru, pada wabah ini. Bahkan di jaman Rosulullah pun sudah terjadi diturunkannya beberapa penyakit, dimulai dari bagian dari masa nabi Ayub kemudian masa pada nabi Muhammad sekalipun, dan memang kita menyikapinya pada setiap posisinya. Artinya ketika kita mendapatkan informasi dari media, bukan berarti kita harus menghindarinya dari segala sesuatu, akan tetapi pada hal yang sifatnya mawas diri atau waspada. Terkadang orang mengartikan ketika ada wabah, mau tidak mau kitapun mendapatkan informasi dari media. Akan tetapi medianya sendiri, terkadang dalam memberikan informasi itu terlalu berlebihan, misalnya bahwa Covid-19 ini adalah penyakit yang sangat-sangat berbahaya, menular dan sebagainya. Akan tetapi kitapun harus menjaga, bukan hanya dilihat dari perspektif hukum positif. Baik secara medis dapat menular melalui percakapan, berkumpul dan lain sebagainya, sampai kita lupa diri. Artinya bahwa sebenarnya itu menjadi salah satu momentum ataupun momen, dijadikan bahwa dari kita itu untuk mawas diri, muhasabah diri, meningkatkan nilainilai keagamaan yang sifatnya spiritual artinya bukan berarti kita menjauhkan diri dan sebagainya, karena ada hal-hal yang lebih penting yaitu meningkatkan ibadah dan sebagainya (Nasrullah Jamal, wawancara, 11 Maret 2021).

Covid-19 yang dijelaskan oleh Pak Nasrul yaitu disangkut-pautkan mengenai wabah yang ada dijaman Nabi Muhammad SAW, begitu juga dengan Nabi Ayub As. Sikap atau tindakan ketika adanya Covid-19 ini berdasarkan posisi masing-masing ketika terkena virus, karena hal itu dapat menjadi penanganan yang berbeda-beda setiap wabah penyakit yang menular. Penjelasan di atas memberikan sikap yang harus dicermati oleh masyarakat, dalam perihal penerima berita oleh media dan oleh setiap orang yang membawakannya. Sehingga menjadikan pemikiran masyarakat lebih luas dan lebih sehat dalam menanganinya.

Yang terakhir yaitu pendapat yang diuraikan oleh Ubaidillah Hidayat, S. HI. Sebagai Bendahra Fkub dan masuk pada Lembaga NU. Beliau menegaskan bahwa Virus Corona-19 itu ada, sudah lama 
bahkan yang lebih parah itu kalo menurut medis yaitu, sebelum tahun 90, itu ada yang dinamakan Mers, Flu Babi, Flu Burung, yang lebih mematikan. Tapi ko kenapa pada umumnya yang diisukan itu hewan-hewan, sekarang malah manusia yang menjadi objeknya, yang kena sasarannya dari yang sekarang yaitu hewan. Sekarang gini aja, ketika kita melihat secara nyata benar tidak orang yang pada tergeletak, pingsan itu disebabkan virus? Justru mereka yang tadinya sehat masuk kerumah sakit malah jadi terkena virus? Kenapa? Karena tadi yang sebelumnya sehat diisolasi, disatu tempat dengan orang-orang yang terkena menjadi positif. Sekarang yang meninggal Covid-19 dirumah ada tidak? Kebanyakan kan di rumah sakit (Pak Ubaidillah Hidayat, wawancara, 04 Mei 2021).

Dari hal yang disampaikan diatas, wabah virus Covid-19 ini sudah ada, bahkan ada yang lebih parah, beliau menyamakan Covid-19 dengan penyakit-penyakit sebelumnya yang hampir serupa, namun yang membedakannya dari penamaan wabah penyakit tersebut. beliau juga menambahkan bahwa Covid-19 ini menyerang ketika orang berada di tempat masyarakat yang terkena virus, misalnya ada orang yang sedang menjenguk di rumah sakit meskipun keluarganya tidak terjangkit Covid-19 namun karena rumah sakit tersebut memiliki pasien yang terkena Covid-19, dapat dinyatakan bahwa orang yang menjenguk tersebut diponis terkena Covid-19. Karena dari penyerangan Covid-19 ini sangat cepat, oleh sebabnya jangan mendekati orang yang terkena Covid-19 yang masih dalam ruang atap yang sama. Dapat disimpulkan bahwa jangan ada yang mendekati daerah yang sama, dan tetap menjaga diri dalam ruangan yang berbeda.

\section{Lembaga Persatuan Islam}

Dalam hal ini dari lembaga Persatuan Islam (PERSIS) memberikan makna yang hampir sama dengan pandangan-pandangan dari lembaga yang sebelumnya, yang membedakan yaitu Persis memberikan penjelasan sejarah wabah penyakit menular dengan panduan yang diterapkan dalam sejarah tersebut berikut pemaparan dari para tokoh agama yaitu, tokoh agama yang pertama bernama H. Erdian (Sekretaris Bidang Jamiyah PP Persis tahun 2015-2020) ia mengatakan bahwa, untuk memahami Covid-19, kita tidak bisa terlepas dari tinjauan historis atau sejarah mengenai epidemic atau pandemic bahkan dijamannya Rosulullah Saw dan para sahabatnya. Dijaman Rosulullah Saw dulu terjadi apa yang disebut dengan wabah dan Rosulullah Saw menanggapi penyakit menular ini beliau memberikan panduan kepada kita sebagai umatnya. Panduannya adalah hendaklah kita melakukan ihktiar, baik yang bersifat lahiriaah maupun batiniah. Jadi ada pendekatan yang bersifat fisik dan ada pendekatan yang bersifat spiritual. Maka pendekatan yang bersifat fisik dan spiritual mesti kita lakukan di dalam merespon mengenai Covid-19 atau pandemic Covid-19, sehingga kita cukup seimbang atau komprehensip dan kholistik menyikapi persoalan Covid-19 ini (Erdian, wawancara 26 Mei 2021).

Covid-19 sangat melekat dengan sejarah-sejarah dahulu yaitu ketika dijaman Rosulullah, kemudian terjadi-pula dijaman para sahabat setelah Rosulullah. Dalam pemaparan yang dikatakan oleh pak Erdian yaitu terdapat adanya panduan atau dikatakaan langkah-langkah untuk menghindari wabah tersebut, yang berasal dan harus dilakukan oleh manusia yang terdampak itu. Panduanpanduan juga dapat menjadi bekal bagi masyarakat khususnya lembaga dalam menghadapi Covid-19 yang sekarang sedang terjadi.

Ada sedikit perbedaan pernyataan yang diberikan mengenai Covid dari pandangan satu dengan pandangan kedua, dari pandangan kedua yaitu oleh Dr. H. Ihsan Setiadi Latief sebagai Wakil Rektor I di Universitas Persis, beliau mengatakan bahwa; "Covid-19 itu nyata, bukan ilusi, bukan konspirasi, Covid-19 itu nyata karena di sekeliling kita ada (Ihsan Setiadi Latief, wawancara 21 Mei 2021). Menegaskan bahwa yang dinamakan Covid-19 itu ada, dan kenyataan itu ada karena terdapat penularan pada lingkungan disekitar kita. Sehingga kita tidak bisa membantah mengenai Covid-19 itu bohong, karena pada realitasnya Covid-19 itu ada dengan memperlihatkan adanya dilingkungan sekitar.

Berbeda juga dengan pandangan dari narasumber yang ketiga yaitu diambil dari penjelasan Haris Muslim, Lc., MA (Sekretaris Umum PP Persis) yaitu; “Yang membedakan adanya Covid-19 buat orang beriman itu menjadi ujian, buat orang yang lalai menjadi peringatan tapi buat orang yang ingkar bisa 
jadi sebagai adzab (Haris Muslim, wawancara, 07 Mei 2021). Pak Haris memberikan pemaparan bahwa Covid-19 itu ada sebagai tanda suatu dampak kepada manusia, sehingga dampak tersebut dapat berupa baik ataupun buruk, itu tergantung manusianya sendiri yang memahami sebab dari munculnya Covid-19.

Dari semua lembaga keagamaan menanggapi Covid-19 yaitu, bahwa disetiap pandangan para tokoh lembaga keagamaan melihat apa yang terjadi dengan munculnya Covid-19 itu, dilihat dari jaman sejarah masa lampau sebelum munculnya Covid-19. Dengan begitu manusia dijaman sekarang mau tidak mau, mempercayai bahwa Covid-19 itu ada. Wabah Covid-19 ini dapat menular dari manusia satu ke manusia lainnya. Oleh sebab itu sejarah dahulu menegaskan manusia di jaman sekarang harus bisa mangambil pelajaran dan pemahaman mengenai pencegahan yang terhadap wabah virus. Karena di jaman sekarang manusia pandai dalam mengembangkan dan membuat tekhnologi yang semakin canggih, dengan begitu manusia dijaman sekarang seharusnya dapat memecahkan masalah Covid-19 ini dengan cepat dalam masalah penyembuhannya.

Pemahaman pada suatu nilai agama, seharusnya manusia dapat memahami dengan mendalami tentang zat Maha Pencipta dan pengontrolan pada setiap tubuh yang terdapat di dalam manusia. Yang bersifat rohani maupun jasmani. Manusia diharuskan berpikir kembali mengenai tindakan-tindakan yang dilakukan pada kehidupannya.

\section{Bentuk Doktrin Tokoh Agama dalam Pencegahan Covid-19 terhadap Umat}

\section{Lembaga Muhammadiyah}

Doktrin ini yaitu suatu hal yang dapat membuat masyarakat memahami dan meyakini bahwa Covid-19 ini dapat disembuhkan dan ada pemecahan masalahnya. Berikut ini doktrin diberikaan kepada umat khususnya dari tokoh keagamaan yang pertama dari lembaga Muhammadiyah yaitu untuk umat, agar menjaga kesehatan, dengan kesehatan itu kita bisa beribadah dengan maksimal lagi, menghindari sakit lebih baik daripada harus mengobati. Jadi kita utamakan untuk menghindari penyakitnya daripada mengobatinya. Untuk beribadah, melakukan peribadatan sesuai dengan kemampuan aturan dan sistem beribadah dalam kondisi darurat, dan paling utama apapun kondisinya, baik darurat ataupun tidak umat harus lebih dekat dengan Allah, lebih banyak lagi beristigfar mohon ampun dan berintropeksi dan banyak lagi berdizkir lagi kepada Allah (Kelik Nursetiyo Widiyanto, wawancara, 09 April 2021).

Doktrin yang diberikan oleh pak Kelik berupa saran untuk umat, beliau memberikan pula penyadaran bahwa kita sebagai manusia harus bisa menjaga dirinya masing-masing. Sebelum adanya pencegahan maka kita hrus menaati peraturan yang diterapkan, agar setiap peribadatan yang dilakukan dapat memberikan hasil yang baik dan benar sesuai system yang berlaku, dalam aturan umum ataupun agama.

Doktrin tersebut ditambahkan dengan pendapat dari tokoh keagamaan selanjutnya pemaparannya sebagai berikut; bahwa edukasi bahwa pandemic ini ada nyata, berada disekitar kita dan tentu saja kita harus selalu mengingatkan masyarakat untuk waspada, bukan saja masyarakat khususnya diri kita dan keluarga untuk tetap melakukan $5 \mathrm{M}$, memakai masker, mencuci tangan pakai sabun, menjaga jarak, menghindari kerumunan dan tidak melakukan banyak kegiatan di luar (Wawancara dengan (Wawancara dengan Iu Rusliana. Pw Muhammadiyah Jawa Barat. Dilakukan pada tanggal 09 April 2021).

Dari pembahsan diatas bahwasannya tokoh agama harus memberikan contoh kepada masyarakat dalam pencegahan Covid-19 ini. Juga memberikan pengingatan kepada masyarakat agar Covid-19 dapat ditangani dengan cepat. Pengingatan tersebut berupa pendidikan, dan dakwah serta komunikasi yang harus dijalankan kepada masyarakat melalui media.

\section{Lembaga Nahdlatul Ulama}

Adapun doktrin yang diberikan kepada masyarakat dari lembaga NU yaitu akan dijelaskan oleh para tokoh keagamaan, hal tersebut dipaparkan sebagai berikut; yakni mengingatkan kembali dalam 
sundanya panggeuing agar orang itu mengingat kembali keberadaan Allah Swt. Begitu juga situasi seperti Covid-19 ini, manusia sudah berada pada keadaan yang sangat maju, pikirannya juga smart atau meluas, modern dan sebagainya. Keadaan jaman juga bisa dilihat sendiri, tekhnologi semakin luar biasa perkembangannya, computer, hp, media social dan alat-alat digital sebagainya. Semua itu terkadang membuat manusia lupa, bahwa ada kekuatan yang Maha Dahsyat dibalik semua itu yakni Allah Swt. Jadi taati anjuran dari pemerintahmu, sebagaimana yang diperintahkan di dalam Al-Qur'an bahwa (taatilah Allah, Rosul dan juga pemerintah) (Wahyi Afif Algoifi, wawancara, 09 April 2021).

Dari uraian di atas, doktrin yang diberikan kepada masyarakat berupa diingatkan kembali pada jalannya yaitu kembali pada adanya Tuhan Yang Maha Esa. Peringatan tersebut bersinambungan dengan nilai agama, yaitu manusia diharuskan atau diwajibkan pada kekuatan yang Maha dahsyat yaitu Tuhan yang menciptakan manusia Allah Swt. Hal tersebut mengharuskan umat untuk menaati peraturan yang telah diperintahkan dalam kitab suci khususnya kitab suci di dalam agama Islam AlQur'an.

Doktrin tersebut dikuatkan oleh pendapat dari tokoh keagamaan kedua, berikut penjelasan doktrin yang diberikan; Doktrin yang diberikan kepada masyarakat yaitu pengetahuan mengenai: pertama, Rendah hati; kedua, Mendapat keyakinan bahwasannya Allah itu man kholiqul syaiing, ala quli syaiing qodir disitu kita menanamkan secara teologi. Kemudian setelah menambah keyakinan banyak aspek social yang kita rasakan adanya Covid-19 ini yaitu: 1. Kita berada di rumah, yang bekerja, yang selama ini meninggalkan rumah dari anaknya, ketika sedang kondisi tidur, dan balik lagi ke rumah dalam kondisi tidur, kemudian tidak tahu anaknya di rumah masih hidup atau tidak, tapi ketika kondisi seperti ini mereka sering dirumah; 2. Sering silahtuhrami sama sekitar warga, karena sering berkumpul. Itu sisi positifnya. Dari segi aspek sosialnya gitu, kalau seandainya doktrin yang diterapkan, pastinya kesabran secara globalnya (Ubaidillah Hidayat, wawancara, 09 April 2021).

Penjelasan doktrin yang diberikan oleh pak Ubaidillah yaitu tentang bagaimana masyarakat berperan sebagai manusia yang beragama dalam menghadapi Covid-19. Peran manusia beragama ini perihal untuk penguasaan nilai yang terdapat pada jiwa. Beliau juga memberikan doktrin dengan nilai teologi yaitu bahwa Tuhan yang menakdirkan ini semua, adapun aspek selanjutnya mengenai aspek social. Dari aspek social ini masyarkat diberikan pengetahua dan pelajaran yang diambil dengan menyimpulkan sisi positif ketika muncul wabah Covid-19.

\section{Lembaga Persatuan Islam}

Lembaga dari Persis terdapat doktrin yang diberikan dari tokoh agama kepada masyarakat khususnya kepada umat yaitu; Kita memberikan pengertian dari aspek ruhiyah, dari aspek spiritual, karena dokter pandangannya atau pendekatannya lebih ke secara rasional.Wabah ini bisa hilang dengan $3 \mathrm{M}$ atau $4 \mathrm{M}$, menjaga jarak, memakai masker, mencuci tangan, menghindari mobilitas. Tapi yang tidak kalah pentingnya yaitu bagaimana kita berdoa kepada Allah swt atau mengajak kepada seluruh umat islam berdoa agar wabah ini segera berakhir. Tentu saja dengan kita bertaubat, beristigfar, atas kesalahan selama ini dengan apa yang kita lakukan juga kita memohon perlindungan dari wabah ini. Jadi peran tokoh agama itu sangat penting karena dalam upaya bagaimana selain dari aspek pendekatan kedokteran juga pendekatan spiritual atau ruhani.

Penjelasan yang diberikan pak Ikhsan mengenai Doktrin kepada umat yaitu dengan memberikan pemikiran dalam hal perasaan atau secara pengertian dari aspek yang bersangkutan dengan ruhiyah atau semangat manusia dan aspek spiritual yaitu batin di dalam diri manusia. Kemudian beliau juga memberikan pemikiran yang positif bagi masyarakatnya bahwa Covid-19 ini dapat di hilangkan dengan melaluui $4 \mathrm{M}$, dan melakukan pembersihan diri atas dosa-dosa yang telah dilakukan.

Doktrin yang diberikan pada masyarakat juga dapat dilakukan oleh tokoh agama selanjutnya berdasarkan lembaga Persis, berikut pemaparan doktrin yang diberikan; yakni mencoba untuk memberikan edukasi, memberikan paradigma kepada masyarakat. Jadi hendaklah melakukan pendekatan ini, pendekatan baik secara sains tekhnologi dalam perspektif medis maupun juga dalam pendekatan keagamaan. Artinya lebih kepada pendekatan-pendekatan spiritualitas, maka jika ini kemudian dilakukan dan paham bagi masyarakat ini tentu akan melahirkan masyarakat yang cukup 
dewasa, cukup cerdas menyikapi persoalan covid 19 (Erdian, wawancara, 09 April 2021). Memberikan pemahaman kepada masyarakat tentang hakikat musibah. Mengajak untuk memahami dan mengenal musibah yg terjadi saat ini. Mengajak untuk memaksimalkan usaha dan ikhtiar sebagai bagian dari ketawakkalan. Memberi contoh (Haris Muslim, wawancara, 09 April 2021).

Dari penjelasan doktrin diatas yang diberikan oleh pak Erdian dan pak Muslim, bahwasannya tokoh agama memberikan suatu edukasi, paradigma keepada masyarakat. Juga melakukan langkahlangkah dengan menerapkan pendekatan-pendekatan yang dilakukan oleh masyarakat. Pendekatan tersebut berupa pendekatan medis dan agama, sehingga spirit yang terdapat di dalam jiwa masyarakat terus berkembang dan positif dalam menanggapi adanya Covid-19. Hasil dari doktrin ini akan melahirkan paham yang didapatkan oleh masyarakat, khususnya umat. Hasil dari pemikiran tersebut yaitu manusia dapat memahami mengenai hakikat musibah yang muncul, dapat memaksimalkan usaha yang dilakukan dan mendapatkan apa yang sudah dijalankan dari perilaku tawakal.

Dari ketiga lembaga tersebut mengenai Doktrin yang diberikan kepada umat yaitu, tokoh agama memberikan pemahaman yang luas, memberikan pencerahan untuk jiwa-jiwa yang sedang merasakan ketidak-stabilan karena munculnya wabah Covid-19. Dengan diberikan langkah-langkah atau paradigm kepada masyarakat dalam pencegahan Covid-19, akan melahirkan jiwa-jiwa masyarakat yang kuat dan akan selalu mengingat tentang ke-Esaan Tuhan.

\section{Peran Lembaga Keagamaan dalam Masyarakat}

\section{Lembaga Muhammadiyah}

Peran lembaga ini sangat penting bagi masyarakat khususnya umat yang bergabung dengan lembaga keagamaan tersebut, selain dapat membantu individu di dalamnya, juga dapat mengembangkan apa yang dimiliki oleh setiap individu. Berikut peran dari lembaga keagamaan Muhammadiyah dijelaskan oleh para tokoh keagamaan sebagai berikut; untuk Muhamadiyah sesaat setelah ada wabah Covid-19 menyebar diberbagai daerah Indonesia, Muhamadiyah segera membentuk dinamakan dengan MCCC (Muhammadiyah Covid 19 Coment Center). Lembaga ini didirikan untuk menanggulangi juga membantu umat yang terdampak dan terkena virus, apakah mereka yang isolasi mandiri atau isolasi di rumah sakit. Jadi Muhammadiyah mengikuti aturan pemerintah untuk meliburkan sekolah, kuliah dan beberapa lembaga lainnya. MCCC ini berkejasama dengan RS Muhammadiyah yang ada di beberapa kota yang ada di Indonesia, sekitaran 40 RS Muhammdiyah dan Aisyiah, juga sekolah tinggi kesehatan di mana mereka yang berada di garis terdepan untuk penangulangan Covid-19. Bahkan sudah ada belasan dokter dari Muhammadiyah yang meninggal saat menangani Covid-19, dan perawat. Ada juga beberapa RS yang perwatnya pernah kita isolasi juga.

Berikutnya adalah yang kita lakukan tentu saja mendukung fasilitas kesehatan yang memadai secara umum, misalkan Muhamadiyah itu memberikan khusus untuk berbagai langkah yang bisa dilakukan, baik di rumah sakit milik Muhammdiyah, dan kami para anggotanya tentu juga ikut serta membantu melalui lembaga Amil Zakat Lazismu Muhammadiyah. Lazismu adalah lembaga Muhammadiyah secara resmi yang melakukan pengumpulan dan melakukan gerakan-gerakan donasi keapda masyarakat yang terdampak (Iu Rusliana, wawancara, 09 April 2021).

Dari pemaparan mengenai peran lembaga keagamaan yang terdapat pada organisasi Muhammadiyah yaitu lembaga Muhammadiyah membentuk gerakan-gerakan yang mempermudah masyarakat khususnya pemerintah dalam melaksanakan tugasnya sebagai pengurus Negara. Kemudian ada gerakan Amil Zakat Lazismu Muhammadiyah yang melakukan pengumpulan dana bagi masyarakat yang membutuhkan karena dampak Covid-19. Dalam melakukan gerakan-gerakan tersebut, tentu saja lembaga Muhammadiyah memberikan kontribusi dan memberikan fasilitas untuk masyarakat. Oleh sebab itu peran dari lembaga Muhammdiyah diperlukan oleh masyarakaymasyarakat Indonesia.

Lembaga Nahdlatul Ulama 
Langkah gerakan dari peran lembaga keagamaan dapat dicontohkan juga oleh lembaga NU, di mana lembaga NU ini membuat gerakan yang akan membantu masyarakat atau Umat, yang dipaparkan sebagai berikut; ada gerakan yang terdapat di lembaga kami yaitu NU Care, kami menyiapkan 6 bulan gratis untuk orang dan bagi yang mau dirawat, juga kalau yang meninggal itu ada ambulannya dari PWNU, banyak yang terkena dari virus Covid-19 khususnya para Kiyai. Pencegahan yang dilakukan dengan melakukan semprot disimpektan segala macam ke pesatrenpesantren, memberikan masker ke pondok-pondok dan juga sekolah-sekolah yang di bawah naungan NU. Ada juga melakukan penyuluhan, kami juga menggandeng pemerintah untuk lakuan sosialisasisosialisasi, tidak hanya berbicara saja melainkan bantuannya pun di berikan. Kerja sama dengan pemerintah juga dilakukan ada bantuan terdampak Covid-19 dan sebagainya,itu juga dilaksanakan (Wahyi Afif Algoifi, wawancara, 09 April 2021).

Penjelasan yang diambil dari peran lembaga NU tersebut yaitu, lembaga NU memiliki gerakan yang dinamakan dengan NU Care, gerakan tersebut yang memberikan peran untuk membantu masyarakat dan pemerintah dalam kasus Covid-19. Fasilitas tersebut diberikan kepada masyarakat yang terdapampak khususnya yang terdapat di dalam lembaga NU sendiri.

\section{Lembaga Persatuan Islam}

Lembaga Persis memberikan peran kepada masyarakat secara umum dengan membantu masyarakat secara gotong royong, yang dipimpin oleh tokoh masyarakat juga tokoh di dalam lembaga itu sendiri. penjelasan tersebut akan dipaparkan oleh tokoh keagamaan, sebagai berikut; maka tentu ini tidak bisa dipecahkan problem" dari Covid-19 ini hanya oleh pemerintah, jadi pemerintah cukup kerepotan untuk kemudian menyelesaikan persoalan ini, tapi persoalan ini harus diselesaikan oleh semua peran serta masyarakat termasuk posisi ormas-ormas Islam atau kelembagaan. Jadi artinya lembaga dalam unit ormas tentu dalam memposisikan cukup di depan dalam memberikan penguatanpenguatan ruhiyah kepada masyarakat termasuk juga melakukan gerakan-gerakan real, ekonomi kepada masyarakat. Jadi kita melakukan gerakan-gerakan sosial, pembagian sembako, membantu orang yang sakit, dengan mensinergikan dari kelembagaan kita. yaitu ada yang namanya Pusat Zakat Umat, ada Sigab Persis. Maka tentu lembaga-lembaga ini kita sinergikan, termasuk terhadap lembagalembaga yang lain. Pesantren bagaimana para mubalig juga memberikan pencerahan, memberikan penguatan-penguatan dari sisi spiritualitas. Jadi lembaga-lembaga yang ada tentu disinergikan bagaimana memberikan solusi terhadap persoalan Covid-19 (Erdian, wawancara, 09 April 2021).

Lembaga keagamaan di Indonesia itu atau tokoh-tokoh keagamaan sangat sentral, misalnya tentang kempen $3 \mathrm{M}$ atau $4 \mathrm{M}$, ada vaksinasi. Bukan hanya pemimpin formal, dari mulai Presiden, Mentri, Gubernur, Bupati, Walikota, sampai level yang paling rendah RT/RW tapi juga informal leader itu sangat diperhitungkan, bahkan mungkin sebagai penentu. Lembaga keagamaan menjadi mitra pemerintah dalam memberikan edukasi kepada masyarakat tentang bahaya Pandemi dan pentingnya kita memaksimalkan usaha pencegahannya (Ihsan Setiadi Latief, wawancara, 09 April 2021).

Dari ketiga tokoh tersebut bahwa lembaga Persis juga memiliki gerakan khusus yang dibuat yaitu dinamakan dengan Pusat Zakat Umat dan ada Sigab Persis. Adapun peran dari lembaga dibantu oleh para tokoh mubalig yang memberikan penguatan kepada pendidikan yang berada di pesantren dalam peningkatan jiwa spiritnya. Gerakan dari lembaga Persis ini tidak jauh berdasarkan hubungan dengan pemerintahm, yang ikut serta membantu, mengawasi dan memberikan peran penting bagi masyarakat khususnya yang terdapat di dalam anggota kelembagaan. Peran yang dilakukan oleh lembaga keagamaan terhadap masyarakat yaitu, dibuatnya suatu gerakan dari lembaga yang berbeda,namun memiliki peran yang sama dalam menanggulangi pencegahan terjadinya Covid-19. Untuk Negara peran dalam lembaga keagamaan itu sangat dipentingkan khususnya di dalam Negara Indonesia yang memiliki ragam lembaga disetiap keagamaan.

Dari peran-peran lembaga diatas sangat berpegaruh dalam membantu masyarakat ketika Covid19 ini mulai menyebar dengan begitu cepat dan pemerintah mulai kewalahan dengan kasus banyaknya dampak Covid-19. Kemudian peran lembaga inilah yang membantu gerakan pemerintah dalam penanggulangan dari dampak terjadinya wabah. 


\section{Tatacara Ibadah Ketika Pandemi Covid-19}

Lembaga Muhammadiyah

Praktek ibadah yang dilakukan oleh setiap umat pasti memiliki sedikit perbedaan dalam melakukannya, berikut yang dirasakan oleh umat agama dalam ibadah ketika ada Covid-19; ada perbedaan ibadah ketika terjadinya Covid-19 dengan sebelumnya, ketika harus beribadah di rumah dan di tempat ibadah. Tapi ini kan dalam kondisi darurat, artinya tidak selamanya seperti ini, suatu waktu mungkin kita akan kembali dalam kehidupan normal dan berjamaah di dalam mesjid. Jadi kita ikuti saja seruan pemerintah, seruan ahli kesehatan. Sehingga kita menyelamatkan diri sekarang, itu lebih baik dahulu. Pada akhirnya ada ibadah-ibadah yang lainnya yang bisa dilakukan. Misalnya solat jum'at, ya dilakukan solat dzuhur saja, jadi bukan berarti tidak beribadah, melainkan beribadah dalam bentuk yang berbeda.

Dari pemaparan pak Kelik bahwa, ada perasaan yang berbeda ketika beribadah biasanya yang dilakukan berjamaah di mesjid kemudian beralih di rumah, namun bukan berarti dengan adanya perbedaan tersebut membuat masyarakat mengabaikan ibadahnya (M Yusuf Wibisono, 2021). Pada prinsipnya ibadah akan terus dilakukan meskipun tempatnya berbeda, dan adapula sedikit perbedaan dari ibadah yang biasanya.

Adapun dari tokoh keagamaan berikutnya yang memberikan pendapat mengenai perbedaan praktek ibadah ketika masa pandemic dengan yang sebelumnya dapat dipaparkan sebagai berikut yaitu; jadi kita berusha untuk bagaimana pandemic ini segera berakhir, saya kira itu komitmen awal. Kalau memang protocol kesehatan tidak dipenuhi ya tidak mengapa, tempat ibadah itu di tutup. Karena kita harus berhati-hati dalam hal itu, saya misalkan lebih memilih solat berjamaah di mesjid kampus, solat jumat di mesjid kampus dibanding solat jumat atau berjamaah mesjid di lingkungan rumah, itu juga salah satu bagian dari praktek serius pemenuhan protokal kesehatan. Saya melihat misalakan mesjid di kampus kita di Uin Bandung, maksudnya terpenuhi protocol kesehatan yang dari penjagaan jarak dan seterusnya, nah ini juga sebagain dari upaya bagaimana kita ingin tetap menjaganya (Iu Rusliana, wawancara, 09 April 2021).

Dari penjelasan diatas beliau memberikan pandangan bahwa kita harus memiliki komitmen yaitu menerapkan peraturan protokol kesehatan, jika aturan dari peraturan tersebut tidak terpenuhi maka diperkenankan untuk tidak beribadah di tempat ibadah atau melakukan jamaah bersama. Karena keseriusan dalam pencegahan dari Covid-19 ini harus tetap dilakukan untuk mengurangi adanya penyebaran virus.

\section{Lembaga Nahdlatul Ulama}

Praktek ibadah dalam lembaga NU akan dipaparkan oleh tokoh keagamaan yaitu; ketentuan ibadah di rumah dan penutupan tempat ibadah secara ilmu menghadapi Covid-19 ikhtiar untuk bisa keluar dari Covid-19 ini dengan menjaga jarak dan sebagainya itu diperbolehkan, kenapa? Kita bisa lihat rujukannya dari orang yang berada di Masjidil Harom, di sanah juga haji-haji dilarang sampai sekarang. Itu yang menjadi rujukan kaum muslimin seluruh dunia untuk ibadah.

Dalam melakukan ibadah harus pakai ilmu beragama itu tidak hanya perasaan semata, nanti kita salah. Jadi silahkan untuk kaum muslimin, semakin mempelajari tentang agamanya kepada yang ahli yang agama beneran, yaitu mereka yang belajar kepada institusi-institusi yang semestinya, kepada guru-guru yang bersanad keilmuan dengan mata rantai yang tersambung dengan Rosulullah Saw. Jika tidak dia beragama dengan akalnya sendiri, yaitu dengan perasaannya, bukan dengan ilmunya.

Dilainsisi kita juga diingatkan bahwa semua tempat-tempat ibadah ketika Covid-19 melanda dihimbau untuk menutup diri atau membatasi orang beribadah disitu. Hal tersebut mengingatkan kita juga dengan Makkah, Madinah yang dipakai untuk orang beribadah haji dan umrah itu sampai ditutup, kita bisa bayangkan, Allah itu tidak butuh ibadah kita yang jelek itu, dengan segala niat pamer dan lain sebagainya. Kemudian Allah itu memaksa kita untuk menyadari "hey kamu harus sadar yang butuh ibadah itu manuasia kita semua hambanya, bukan Allah yang butuh kamu, ditutup Ka'bah, ditutup kota Madinah, ditutup smua tempat-tempat ibadah, semua agama bahkan, itu tidak membuat 
kekuasaan Allah jadi berkurang, seharunya kita merasa ingat hal sperti itu (Wahyi Afif Algoifi, wawancara, 09 April 2021).

Dari penjelasan diatas mengenai perbedaan ibadah yang biasanya dengan ibadah ketika dilanda Covid-19, yaitu ibadah dilakukan dengan ilmu agama (Truna, 2013). Artinya ketika kita ingin melakukan ibadah yang berbeda dengan sebelumnya diwajibkan kita harus tahu ilmu dari ibadah tersebut,karena apabila ibadah tidak berdasarkan ilmu maka aka nada penyimpangan dalam praktepraktek ibadah yang dilakukan. Pak Afif juga melihat gambaran dari tempat ibadah yang menjadi pusat tempat ibadah terkhususnya dalam agama Islam yaitu Ka'bah, Makkah dan Madinah. Dari pusat tempat ibadah tersebut dijadikan sebagai contoh bagi tempat ibadah diseluruh dunia.

Kemudian pendapat itu juga diperkuat oleh tokoh keagamaan dari lembaga yaitu; ketika kita berbicara disini dengan para pemuka agama, mereka juga sama, ketika dalam posisi kondisi mereka sekarang ini, kita harus betul" berpikir bahwasannya kita tidak ada daya upaya kecuali memahami kekuasaan. Kami mencari tuhan di tempat ibadah, tpi ketika tmpat ibadah tersebut dilarang untuk dimasuki mau kmna? Bahkan baitullah sendiri ditutup, itulah proses pencarian (Rosyad, 2007). Kalau dikita pasti, dengan adanya covid ini, menambah keyakinan terhadap Allah, menambah pendekatan kita terhadap Allah atau taqarub. Kemudian di sisi lain jua dengan memperbanyak dzikir, artinya banyak dirumah yang intinya pencapaian-pencapaian spiritual yang dilakukan di rumah, artinya tidak mesti dilakukan tempat ibadah, kita bisa menetapkan masalah ini dengan keluargaSelain itu Pak Ubed menjelaskan bahwa dengan adanya Covid-19 kita masih bisa memperbanyak mengingat Allah dan melakukan ibadah di rumah, artinya pendapat tersebut tidak mempermasalahkan di mana kita beribadah, melainkan bagaimana kita dekat dengan Tuhan (Ubaidillah Hidayat, wawancara, 09 April 2021).

\section{Lembaga Persatuan Islam}

Kemudian ada pembantahan dari lembaga Persis mengenai penutupan tempat ibadah serta perbedaan ibadah yang dilakukan oleh umat persis yang diuraikan sebagai berikut; tidak ada penutupan tempat ibadah, yang ada itu pembatasan, misalnya edaran kementrian agama bahkan MUI sendiri kan menyampaikan, ada pembatasan bukan hanya tempat ibadah saja, melainkan juga hotel, tempat pertemuan, seminar, bahkan muhtamar sekalipun, dari kapasitas yang sebenarnya (Rahman, 2011). Misalnya kapasitas dari jumlah sesungguhnya, saya kira itu hal bisa kita mampumi, apalgi kita melihat di Saudi Arabia, itukan ada juga pembatasan. Artinya pembatasan-pembatasan, menjaga jarak meskipun memang dikalangan umat Islam perdebatan tentang, misalnya shaf yang rapat, karena kan keapdoliannya pun itu luruskan dan rapatkan sedangkan dalam masa pandemic itu, luruskan dan renggangkan. Tapi kan ini dalam situasi pandemic situasinya post mager, terkena wabah, saya kira hal yang biasa (Ihsan Setiadi Latief, wawancara, 09 April 2021).

Uraian yang diberikan oleh pak Ikhsan mengenai praktek ibadah yang dapat dilakukan di mesjid secara berjamaah, karena tidak ada aturan mengenai penutupan tempat ibadah, melainkan aturan pembatasan-pembatasan dari dilakukannya praktek ibadah. Tentu yang bersifat amal jama'I atau suatu perbuatan yang dilakukan berjamaah seperti solat berjamaah di mesjid tentu akan berbeda rasanya ketika dilakukan hanya sendirian atau hanya dirumah saja. Sehingga tidak semata-mata kemudian bagaimana ada hadits-hadits mengenai spirit, menyemangati bagaimana kita supaya memakmurkan mesjid baik dalam memakmurkan fisiknya maupun memakmurkan ruhnya. Kemakmuran ruhnya itu salah satunya adalah dengan melakukan berbagai aktifitas dimesjid, salah satu yang terpenting adalah melakukan solat berjamaah di masjid (Erdian, wawancara, 09 April 2021). Selain itu juga harus konsisten dari pemangku kebijakan dalam menerapkan aturan. Tidak diskriminatif sehingga mengesankan seolah tempat ibadah menjadi sumber wabah (Haris Muslim, wawancara, 09 April 2021).

Dilihat dari penjelasan yang diberikan oleh kedua tokoh tersebut saling berkaitan satu sama lain. Ketika dari pak Erdian memberikan pendapat bahwa ada perbedaan dilakukannya ibadah berjamaah di mesjid dengan ibadah sendiri di rumah. Oleh sebab itu beliau memegang ajaran yang dibahas pada pemaparan hadits-hadits (Rosyad, Mubarok, Rahman, \& Huriani, 2021). Di mana di atas disebutkan bahwa perlu adanya tindakan spirit untuk menghidupkan mesjid dengan melakukan aktifitas di 
mesjid. Penguatan pendapat tersebut ditambahkan oleh tokoh dari pak Muslim, bahwasannya harus adanya konsistensi terhadap aturan kebijakan yang diterapkan, sehingga tidak berdampak timbulnya tindakan diskriminatif yang mengesankan bahwa tempat ibadah itu seolah-olah menjadi sumber dari munculnya wabah (Truna, 2013).

Dari ibadah yang dilakukan oleh pandangan para tokoh yaitu terdapat perbedaan ketika beribadah bersama atau berjamaah di tempat ibadah dengan yang sendiri atau di rumah. Namun hal tersebut bukan berarti bahwa tempat ibadah tidak boleh digunakan oleh masyarakat, hanya saja aturan dari pemerintah kepada masyarakat harus memiliki kewaspadaan dalam menyikapi Covid-19 ini. Karena untuk saat ini ibadah di manapun harus tetap dilakukan karena untuk memenuhi kewajiban sebagai umat yang beragama.

Perilaku Keagamaan dalam Sistem Sosial Agama

Lembaga Muhammadiyah

Sikap-sikap yang harus dilakukan ketika adanya Covid-19 pada sistem sosial dapat dilihat dari pemaparan yang dijelaskan oleh tokoh keagamaan yaitu; umat dalam beribadah sudah aturan atau tuntunan dalam kehidupan normal ataupun dalam kehidupan darurat, solat pun ada cara, kemudian beribadah lainpun demikian, jadi kita tinggal mengikuti saja normal bisa dilakukan, kalau darudat bisa dilakukan dengan ketentuan yang sesuai sehingga tidak memberatkan umat untuk beribadat (Kelik Nursetiyo Widiyanto, wawancara, 09 April 2021).

Menurut salah seorang tokoh muda Muhammadiyah:

Jadi jauh sebelum yang lain menentukan sikap, menentukan fatwa-fatwa. Misalkan pada lembaga Muhammadiyah sudah mengingatkan dengan fatwa tentang beribadah di rumah, tentang penetapan protocol kesehatan di tempat ibadah yang dikelola oleh seluruh organisasi Muahmmadiyah. Kemudian kita juga didorong untuk diingatkan slalu menjadi teladan dalam melaksanakan protocol kesehatan secara pribadi dan keluarga khususnya ormas, prinsipnya yaitu tetap $5 \mathrm{M}$, ini bagian dari iktiar kita untuk menurunkan wabah dan jumlah yang positif (Iu Rusliana, wawancara, 09 April 2021).

Dapat ditarik dari kesimpulan penjelasan kedua tokoh tersebut bahwa perilaku keagamaan dalam sistem sosial dalam lembaga Muhamamdiyah berupa mengikuti aturan yang sudah ditetapkan dengan tuntunan berlaku. Begitupula dalam kehidupan social lembaga Muhammadiyah sesuai dengan aturan. Karena lembaga Muhammadiyah telah menentukan sikap dengan dibuatnya fatwa-fatwa yang berlaku untuk para anggota, sehingga diingatkan mengenai praktek-praktek ibadah yang dilakukan.

\section{Lembaga Nahdlatul Ulama}

Sikap perilaku dilihat dari lembaga kegamaan yang terdapat di lembaga NU, dapat dijelaskan sebagai berikut; dalam sebuah perubahan pasti membutuhkan kemampuan orang untuk survepey, tentu saja adaptasi itu menjadi penting, kalau anda dari daerah yang panas ke daerah yang dingin anda harus pake jaket dan sebagainya, untuk apa? Agar kita bisa bertahan terhadap situasi yang berkembang disitu, kalau tidak ya kita akan sakit, menderita sendiri, ketika kita memaksakan tidak untuk mengikuti, tidak beradaptasi dengan situasi yang ada (Muhyiddin, Rosyad, Rahman, \& Huriani, 2020).

Salah seorang tokoh NU Bandung menyatakan:

Maka tentu saja kalau sekarang harus pakai masker dan lain sebagainya. Saya kira ini adaptasi yang positif, diakhir jaman begini, kalau jaman dulu mungkin kurang positif, kalau jaman sekarang positif. Misalnya anak-anak perempuan memakai masker itu kan menutup dari debudebu dan lain sebagainya, jadi tidak melakukan meludah disembarang tempat, menjaga kebersihan, yang sebenarnya semua itu di dalam agama islam sudah ada, anak perempuan dikaum muslimin itu menutup hidungnya, setengah mukanya dengan cadar dan sebagainya. Tergantung kepentingannya kalau dia misalkan di tempatnya merasa aman dan nyaman ya 
bisalah pakai itu, kemudian dijalan dan sebagainya berfungsi untuk menjaga diri (Wahyi Afif Algoifi, wawancara, 09 April 2021).

Penjelasan yang dipaparkan oleh pak Afif bahwa sikap yang dilakukan oleh masyarakat yaitu harus mengikuti aturan berdasarkan tampatnya masing-masing, agar masyarakat mampu beradaptasi dengan lingkungan tempat tinggalnya. Beliau mengatakan bahwa dengan adanya aturan dalam pencegahan Covid-19 ini, agama Islam sudah terlebih dahulu menyikapi kebiasaan yang diterapak dalam ajaran, contoh masker dan ajaran yang diterapkan dalam Islam yaitu cadar untuk perempuan, kemudian berwudlu yang berhubungan dengan $3 \mathrm{M}$, dan lain sebagainya.

\section{Lembaga Persatuan Islam}

Penjelasan mengenai perilaku keagamaan juga akan disampaikan oleh tokoh dari lembaga Persis yaitu; maka inilah hal yang harus disampaikan kepada jamaah, didewasakan dan termasuk, majelis ulama memberikan pandangan-pandangan, masukan-masukan dengan surat edarannya atau fatwa MUI itu dan juga dijadikan sebagai pertimbangan bagi pemerintah dalam mengambil keputusan, sehingga idealnya dalam situasi pandemic ini atau tentu tidak lantas tempat-tempat ibadah, masjid itu ditutup, tetap dibuka tetapi dengan mempertimbangkan protokol kesehatan melihat situasi dan kondisi (Rahman, 2010). Sehingga jamaah tetap spiritualitasnya tuh meningkat, tidak menurun, ada momentum untuk berinteraksi salah satunya adalah interaksi di tempat ibadah (Kuswana, Qomaruzzaman, \& Mahatma, 2020). Salah seorang tokoh Persis menyatakan:

Contoh konkrit misalkan di lingkungan saya maka tidak pernahh yang namanya mesjid itu misalkan tutup untuk melaksanakan solat berjamaah, tetap itu dilakukan tetapi dengan mempertimbangkan, memperhatikan protocol kesehatan, jamaahnya mesti pake masker, kemudian yang flu yang bersin di rumah saja ini terus dilakukan, termasuk juga ada gerakangerakan real bagaimana kita melakukan gerakan social dengan tropi untuk mengantisipasi jika ada warga atau jamaah kita yang terkena dampak, baik terkena dampak secara ekonomi, maupun dampak secara medis kesehatan (Erdian, wawancara, 09 April 2021).

Pemaparan dari Pak Erdian menegaskan bahwa supaya masyarakat bersikap dewasa dalam melakukan atau bertindak permasalahan Covid-19. Kemudian kepada MUI supaya memberikan masukan berupa pandangan kepada masyarakat dalam mengambil keputusan yang diambil. Seperti halnya menmutuskan untuk menutup tempat ibadah, seharusnya tempat ibadah tetap dibuka namun tetap melakukan aturan protokol kesehatan yang berlaku (Kuswana et al., 2020).

Dari ketiga lembaga tersebut ketika menyikapi perilaku keagamaan dalam sistem sosial yaitu dengan kembali bersikap sesuai aturan dari pemerintah dalam pencegahan Covid-19. Karena mau tidak mau di sini pemerintah mengambil keputusan berdasarkan kehati-hatian terhadap virus yang menyebar semakin cepat. Untuk menanggulanginya dengan cara memutus rantai terjadinya penyebaran yaitu dengan diterapkannya aturan kepada masyarakat khususnya di dalam lembaga keagamaan.

\section{Kesimpulan}

Hasil dari pandangan yang ditinjau dari tokoh-tokoh keagamaan mengenai Covid-19 memberikan kajian pemikiran yaitu Covid-19 adalah makhluk yang diciptakan oleh Tuhan terhadap manusia, karena Tuhan ingin mengingatkan manusia agar tidak selalu sombong dengan tindakannya di dunia. Lembaga ini memiliki fungsi dalam menanggulangi, membangun kesejahteraan, memberikan fasilitas kepada masyarakat dan lain sebagainya. Lembaga keagamaan juga memiliki peran terhadap masyarakat yaitu bergerak dalam menolong masyarakat, bergerak membentuk kemunitas-komunitas yang sejalan dengan masyarakat. Peran yang dilakukan oleh lembaga juga memberikan kontribusi sesuai aturan pemerintah kepada masyarakat, memberikan solusi-solusi yang membuat masyarakat merasa tercukupi. Misalnya dalam masalah ibadah, masyarakat harus mengetahui apakah aturan ibadah di rumah atau sendiri diperbolehkan atau tidak, dan apakah tempat-tempat sacral lainnya 
diijinkan untuk tetap didatangi atau tidak, itu semua masuk pada peran lembaga keagamaan. Karena fungsi dan peran keagamaan memberikan waawasan tentang keilmuan bagi masyarakat, karena kalau tidak diberikan ilmu agama maka masyarakat kan bingung, tidak paham dan akan timbul kesalahpahaman pada praktek-praktek agama atau ibadah yang dilakukan.

Tokoh keagamaan yang dapat memberikan ilmu tersebut dengan memberikan ajaran berupa teksteks yan terdapat di dalam Al-Qur'an, hadits dan penguat-penguat ulama besar di dunia. Dari diberikannya ajaran tersebut dapat menghasilkan masyarakat yang bersyukur dengan situasi yang menekan masyarakat. Sehingga masyarakat dapat mengambil hikmah di balik adanya Covid-19 ini. Dari hikmah ini masyarakat juga dapat memahami fungsi dari turunnya wahyu Tuhan kepada manusia, serta manusia harus ingat dan paham bahwa Tuhan memiliki sifat-sifat yang baik. Dengan adanya Covid-19 ini umat harus sabar serta tawakal dalam menghadapinya, karena Tuhan sematamata menurunkan Covid-19 ini bukan untuk menghancurkan manusia, melainkan tindakan dan perbuatan yang salah dari perilaku manusia.

\section{Referensi}

Ansyori, M. (2018). Pembentukan perilaku keagamaan melalui budaya sekolah: studi multi kasus pada SD plus Nurul Hikmah Pamekasan dan MI Sirojut Tholibin I Pamekasan. UIN Sunan Ampel Surabaya.

Darmawan, D., Miharja, D., Waluyajati, R. S. R., \& Isnaeniah, E. (2020). Sikap Keberagamaan Masyarakat Menghadapi Wabah COVID-19. Religious: Jurnal Studi Agama-Agama Dan Lintas Budaya, 4(2), 115-124. https://doi.org/10.15575/rjsalb.v4i2.8596

Darsono, D., Rohmana, J. A., \& Busro, B. (2020). Against COVID-19 Pandemic: Bibliometric Assessment of World Scholars' International Publications related to COVID-19. Jurnal Komunikasi Ikatan Sarjana Komunikasi Indonesia, 5(1), 75-89. https://doi.org/10.25008/jkiski.v5i1.356

Diseko, L. (2020). Virus corona: Apa dampak Covid-19 terhadap tata cara ibadah agama? Retrieved 12 June 2021, from BBC Indonesia website: https://www.bbc.com/indonesia/indonesia-51813486

Firdausita, R. S. (2018). Pengaruh pemahaman agama dan lingkungan terhadap perilaku perempuan hamil di luar nikah di Kecamatan Pucuk Kabupaten Lamongan. UIN Sunan Ampel Surabaya.

Hanafi, H., Syarifudin, S., Nurfaizal, D., \& Nurjanah, S. (2020). Kajian Ontologis Studi Agama-Agama. Prodi S2 Studi Agama-Agama UIN Sunan Gunung Djati Bandung.

Jubba, H. (2021). Beradaptasi dengan Bencana: Strategi Beribadah Umat Islam dan Kristen di Tengah Pandemi Covid-19. Religious: Jurnal Studi Agama-Agama Dan Lintas Budaya, 5(1), 1-14.

Kuswana, D., Qomaruzzaman, B., \& Mahatma, M. (2020). Agama dan wabah: Tanggapan ulama Jawa Barat atas Covid-19 tahun 2020. UIN Sunan Gunung Djati Bandung.

Moleong, L. J. (2021). Metodologi penelitian kualitatif. Bandung: PT Remaja Rosdakarya.

Muchammadun, M., Rachmad, S. H., Handiyatmo, D., Tantriana, A., Rumanitha, E., \& Amrulloh, Z. (2021). Peran Tokoh Agama dalam Menangani Penyebaran Covid-19. Religious: Jurnal Studi Agama-Agama Dan Lintas Budaya, 5(1), 87-96.

Muhyiddin, A., Rosyad, R., Rahman, M. T., \& Huriani, Y. (2020). Urgensi penjelasan keagamaan terhadap keluarga suspek Pasien Dalam Pengawasan (PDP) Covid-19. Hanifiya: Jurnal Studi Agama-Agama, 3(1), 35-42.

Pujiastuti, T. (2017). Konsep Pengalaman Keagamaan Joachim Wach. Jurnal Ilmiah Syi'ar, 17(2), 63-72.

Rahman, M. T. (2010). Pluralisme Politik. WAWASAN: Jurnal Ilmiah Agama Dan Sosial Budaya, 34(1), 1-13.

Rahman, M. T. (2011). Glosari Teori Sosial. Ibnu Sina Press.

Rompas, J., Kawatu, P. A. T., \& Pinontoan, O. (2020). Gambaran Perilaku Pedagang Warung terhadap Pencegahan Covid-19 di Kecamatan Malalayang Kota Manado. KESMAS, 9(7), 137-146.

Rosyad, R. (2007). A quest for true Islam: A study of the Islamic resurgence movement among the youth in Bandung, Indonesia. Australia: ANU Press.

Rosyad, R., Mubarok, M. F., Rahman, M. T., \& Huriani, Y. (2021). Toleransi Beragama dan Harmonisasi Sosial. Bandung: Digital Library UIN Sunan Gunung Djati Bandung.

Salsabila, N. (2020). Perubahan Yang Terjadi Dalam Masyarakat Sebagai Dampak Dari Covid-19. Retrieved 16 March 2021, from FISIP Universitas Brawijaya website: https://fisip.ub.ac.id/?p=10282\&lang=en

Satria, A. B. A. (2020). Pelaksanaan Ibadah Salat Berjamaah Dalam Masa Pandemi Covid-19 Di Kelurahan Kalicacing Kecamatan Sidomukti Kota Salatiga Tahun 2020. IAIN SALATIGA.

Sugiyono. (2009). Kualitatif, dan R\&D. Bandung: Alfabeta.

Suherman, D. (2020). Peran Aktor Kebijakan Pembatasan Sosial Berskala Besar Dalam Mengatasi Penyebaran COVID-19 Di Indonesia. Ministrate: Jurnal Birokrasi Dan Pemerintahan Daerah, 2(2), 51-62. 
Supriatna, E. (2020). Wabah Corona Virus Disease Covid 19 Dalam Pandangan Islam. SALAM: Jurnal Sosial Dan Budaya Syar-I, 7(6), 555-564.

Susilo, A., Rumende, C. M., Pitoyo, C. W., Santoso, W. D., Yulianti, M., Herikurniawan, H., ... Nelwan, E. J. (2020). Coronavirus disease 2019: Tinjauan literatur terkini. Jurnal Penyakit Dalam Indonesia, 7(1), $45-67$.

Tado, A. (2020). Tarik-Ulur Kebijakan Penutupan dan Relaksasi Tempat Ibadah Selama PSBB. Retrieved 17 April 2021, from kumparan news website: https://kumparan.com/kumparannews/tarik-ulur-kebijakanpenutupan-dan-relaksasi-tempat-ibadah-selama-psbb-1tRyQ4sdbkP

Truna, D. S. (2013). Batas Toleransi Dan Identitas Kelompok. In Makalah disajikan di Madrasah Malem Reboan, UIN Sunan Gunung Djati, Bandung tanggal (Vol. 10).

Usman, M. (2020). Pembatasan Sosial Berskala Besar di Indonesia dalam Perspektif Hadis Lockdown. UIN Sunan Ampel Surabaya.

Wach, J. (2019). Sociology of religion. Routledge.

Wibisono, M Yusuf. (2021). Agama dan Resolusi Konflik. Bandung: Lekkas dan FKP2B Press.

Wibisono, Muhammad Y, Truna, D. S., \& Rahman, M. T. (2021). Turning religion from cause to reducer of panic during the COVID-19 pandemic. HTS Theological Studies, 77(4), 1-8.

(C) 2021 by the author. Submitted for possible open access publication under the terms and conditions of the Creative Commons Attribution (CC BY SA) license (https://creativecommons.org/licenses/by-sa/3.0/). 
Halaman ini sengaja dikosongkan 